\title{
Royal Authority in the Biblical Quotations of the Old English Pastoral Care
}

\author{
Amy Faulkner ${ }^{1}$ (D)
}

Published online: 30 October 2017

(C) The Author(s) 2017. This article is an open access publication

\begin{abstract}
The Old English Pastoral Care, a late-ninth-century translation of Gregory the Great's Regula pastoralis attributed to Alfred the Great, is a text without a clear authorial voice. Gregory's authorial presence is hinted at in the metrical preface and epilogue to the translation, but is curiously absent from the prose preface. Here, at the very beginning of the text, the authorial voice is that of King Alfred. Whether or not Alfred was actually responsible for translating the Regula pastoralis, as the prose preface claims, his voice and presence resonate throughout the translation. The king's persona re-voices not only Gregory's words, but the many biblical quotations that Gregory relies upon to support his argument. The royal authority natural to a king is compounded with the textual authority that comes through translating and therefore re-voicing a canonical text such as the Regula pastoralis, and this is nowhere more significant than in the translations of biblical quotations. Here, the Alfred-persona re-voices biblical figures such as King David, King Solomon, the evangelists and Christ Himself. In the translations of these quotations, Alfred's royal authority is shored up by the echoes of these voices from Scripture. This article finds examples of where the wording of these translated quotations represents ideology, and even phraseology, found elsewhere in Alfredian documents. Through appropriation of scriptural voice, Alfredian ideals such as wisdom, moderate use of resources and a ruler's humility are given unquestionable authoritative backing.
\end{abstract}

Keywords Old English · Alfred · Pastoral Care · Gregory

Amy Faulkner

amy.faulkner@spc.ox.ac.uk

1 St Peter's College, University of Oxford, New Inn Hall Street, Oxford OX1 2DL, UK 


\section{Introduction}

In his Regula pastoralis, Gregory the Great frequently turns to scriptural examples as support for his arguments. As the text itself maintains, the ideal preacher should absorb the wisdom of Scripture in meditation and make use of it in the day-to-day tending of his flock. ${ }^{1}$ Sometimes these examples are simply alluded to, but very often Gregory directly quotes from Scripture. In the Old English translation of the text, henceforth referred to as the Pastoral Care, these quotations are translated into Old English with the same degree of free handling as the rest of the text. ${ }^{2}$ As both the prose and metrical prefaces to the Old English Pastoral Care attribute the translation to Alfred the Great, these biblical quotations, like the rest of the text, are heard in the king's voice. ${ }^{3}$ This is the effect of the prefatory material, regardless of whether or not Alfred did actually translate the Pastoral Care himself. ${ }^{4}$ This article will highlight the significance of the presence of these biblical quotations in a text spoken in the king's voice; it will moreover demonstrate that the alterations that the quotations undergo in the process of translation contribute to the construction of the same royal ideology that can be found in other Alfredian translations and in Asser's contemporary portrait of the king. Central to this discussion is the dual authority bestowed upon the persona of Alfred: the royal authority natural to him, and the authority afforded to him through translating and voicing Gregory's text, especially the biblical quotations. In these quotations, Alfred's voice merges with that of a biblical figure, such as Solomon or David, and he appropriates their authority. ${ }^{5}$

Scholarly interest in Alfredian evocation of Scripture and its figures has largely focussed on the association between Alfred and David. In the twelfth century William of Malmesbury credited Alfred with beginning a translation of the Psalter into Old English, which may well correlate to the Old English prose translation of

\footnotetext{
${ }^{1}$ See the exegesis on Ex. 25.12-15 in Regula pastoralis 2.11: 'Quia nimirum necesse est ut quia ad officium praedicationis excubant, a sacrae lectionis studio non recedant' (Judic et al. 1992, vol. I, p. 254, 11. 40-42) ('for it is evidently necessary that they who devote themselves to the office of preaching should never depart from the occupation of sacred reading' [Davis 1950, p. 88]). Likewise, in the same chapter: 'Sed circulis uectes inhaereant, ut doctores semper in suis cordibus eloquia sacra menditantes, testamenti arcam sine mora eleuent: si quid necesse est, protinus decent' (Judic et al. 1992, vol. I, p. 256, 11. 47-50) ('Let the staves remain in the rings: let the teachers, ever meditating in their hearts on the Sacred Word, at once raise the Ark of the Testament, let them teach forthwith when the occasion demands it' [Davis 1950, p. 88]). Both the edition and translation of the Regula pastoralis feature italics to indicate quotation: these have been normalised.

2 Though the Pastoral Care is by far the most faithful of all the translations attributed to King Alfred, it is not as close to the Latin as the Dialogues or the Old English Bede. Bately (1988, p. 126) observes that the translation technique in the Pastoral Care is less 'word for word' than 'sentence by sentence'.

3 These prefaces travelled with the copies of the translation when they were sent to the bishops of Wessex and Mercia. This is evidenced, for example, by Oxford, Bodleian Library, Hatton 20 (S.C. 4113), which contains both the prose and metrical prefaces, and is datable to 890-97; this manuscript is addressed to Bishop Wærferth and bears the inscription 'ĐEOS BOC SCEAL TO WIGORA CEASTRE' ('This book must go to Worcester') (Ker 1990, no. 324, pp. 384-385). See also Schreiber (2003, p. 19, no. 53). All translations from Old English are my own.

4 For an overview of the debate over Alfred's authorship, see the Appendix to Discenza and Szarmach's edited collection on Alfred (2015, pp. 397-415).

5 On Alfred's reproduction of authority through translation, see Stanton (2002, p. 84).
} 
the first fifty psalms in Paris, Bibliothèque nationale de France, Fonds latin 8824 (the 'Paris Psalter') (O'Neill 2001, p. 73). The connections between the two kings, surrounded by their enemies, are readily apparent. Moreover, Toswell (2014, p. 66) has argued that Asser's biography of Alfred draws parallels between the West Saxon king and David: she suggests that for Asser, "Alfred is certainly a contemporary exemplum of David, and possibly, by extension, of Christ. ${ }^{6}$ Orton (2015, p. 480) has recently suggested that the prose translation of the first fifty Psalms is representative of a wider attempt to present Alfred's kingship in Davidic terms. ${ }^{7}$ However, Alfredian appropriation of scriptural authority is not limited to David and the Psalter. In his biography of the king, for example, Asser explicitly mentions Solomon as a model of kingship for Alfred, succeeding in both wisdom and worldly things. ${ }^{8}$ The translated biblical quotations in the Pastoral Care offer another, unexplored avenue for insight into the Alfredian construction of royal authority and ideology through re-voicing Scripture.

\section{The King's Voice}

The first voice that the reader encounters in the Pastoral Care is Alfred's, in the long prose preface. Here Alfred declares that he has translated the Regula pastoralis with the support of his scholarly helpers (Sweet 1871-1872, p. 7, 11. 17-25). ${ }^{10}$ The tone of this preface is intensely personal, for the reader is offered a glimpse of the king's inner thought as he ponders the intellectual state of his people, past and present: the result is a powerful sense of Alfred's presence. It is worth noting that, perhaps surprisingly, Gregory's name is not mentioned at all in the prose preface, only in the following metrical preface and the metrical epilogue. ${ }^{11}$ The metrical preface is spoken not by Alfred but by the text of the Regula pastoralis itself: the

\footnotetext{
6 Toswell (2014, pp. 64-72) further suggests that Asser deliberately models Alfred on David in his biography of the king.

7 Butler (2010, p. 16), has likewise argued that Alfred desired to act as a 'novus David', while Treschow (2014, pp. 176-178) has suggested that the Old English translation of Psalm 28 invites comparison with the contemporary Anglo-Saxon situation, with Alfred seen in Davidic terms. Pratt (2007, p. 242), moreover, has argued that the translation of the first fifty Psalms enables a re-enactment of 'Davidic composition'. See also Godden (1991, pp. 224-225) on the similarities between Alfred's situation and David's, as highlighted through the wording of the introductions to the Prose Psalms.

8 See Vita Alfredi c. 76. Wallace-Hadrill (1971, p. 148) observes that Alfred's 'role is that of Solomon, as Charlemagne's had been that of David'. Moreover, Godden (1991, p. 216) remarks upon Alfred's presentation of himself as a successor of Moses in the preface to the Domboc.

9 Orton (2015, p. 478) argues that the Prose Psalms translation offers just such an opportunity to 'harness the authority of Scripture'.

10 All quotations from and references to the Pastoral Care are taken from the Hatton manuscript, as printed by Sweet (1871-1872); all brackets and italics representing manuscript emendation in Sweet's edition have been normalised.

11 In the prose preface, the Regula pastoralis is referred to only as the book 'ðe is genemned on Læden Pastoralis, \& on Englisc Hierdeboc' (Sweet 1871-1872, p. 7, 11. 18-19) ('which is called in Latin Pastoralis, and in English Hierdeboc'). This anonymity can be contrasted with the preface to the Soliloquies, which mentions Augustine by name as the author of the original text (Carnicelli 1969, p. 48, 1. 13).
} 
text - the most reliable witness - reinforces the claims made in the prose preface, declaring: 'Siððan min on Englisc Ælfred kyning awende worda gehwelc' (Sweet 1871-1872, p. 9, 11. 12-13). ${ }^{12}$ The trope of the speaking book heightens the sense, once the reader actually arrives at the text itself, that a voice issues from the pages of the manuscript: as we know from the prose preface, this voice belongs to the West-Saxon king, rather than the pope. ${ }^{13}$ A chapter list, translated from the Latin, follows the metrical preface, but this precedes not the main text of the Pastoral Care itself, but yet another preface. ${ }^{14}$ This is the same preface that appears in the Regula pastoralis, which takes the form of a letter from Gregory to his colleague Bishop John of Ravenna. While in the Latin text this is titled: 'Reverentissimo et sanctissimo fratri Ioanni coepiscopo, Gregorius' (Judic et al. 1992, vol. I, p. 124, 11. 1-2), ${ }^{15}$ the Old English translation launches into the letter itself without any indication of who is speaking and who is being spoken to. ${ }^{16}$ There is nothing to suggest, therefore, that the voice of this preface and the text that follows does not belong to the only other (human) voice that has been heard so far: King Alfred's. While the author of the main text of the translation takes no pains to indicate that it is Alfred speaking, he curiously makes just as little effort to indicate that the speaker is Gregory. ${ }^{17}$ The translator renders the Gregorian epilogue at the end of the text, identifying John as an addressee here, despite making no mention of him at the beginning (Sweet 1871-1872, p. 467, 1. 18). So much more present is Alfred's voice than Gregory's that one reader has added a note glossing this 'Iohannes' as 'Ælfredes cynges mæssepreost Iohannes' (Godden 2011, p. 465). ${ }^{18}$ Godden (2011, p. 465) suggests that this reader 'interpreted the voice here as Alfred's rather than Gregory's - not unreasonably, given the invisibility of Gregory as author so far.' The strength of Alfred's presence in the translation is, to use Pratt's terminology

\footnotetext{
12 'Afterwards King Alfred turned each word of me into English'.

${ }^{13}$ Discenza (2001a, pp. 625-627 and 629-630) shows how the metrical preface constructs Alfred's authority over his readers, and situates the king in a chain of transmission with Gregory and Augustine of Canterbury. See Earl (1989, pp. 54-56) on the conceit of a text that speaks directly to the reader.

${ }^{14}$ While the translator maintains the same chapter headings as Gregory, he does not separate the chapters into four sections as in the Latin.

15 'Gregory to his most reverend and most holy brother John fellow bishop' (Davis 1950, p. 20).

${ }^{16}$ See Godden (2011, p. 464) on the display of this preface in Latin manuscripts, and the contrast in manuscripts of the Old English translation.

${ }^{17}$ This contrasts with the approach of the Old English translation of Gregory's Dialogi, undertaken by Bishop Wærferth at Alfred's request (see Vita Alfredi c. 77). The Latin text of the Dialogi launches directly into Gregory's first person speech, but in the Old English translation this is prefaced by a certain amount of scene setting: in MS C (Cambridge, Corpus Christi College, 322), a narrator exterior to Gregory and his interlocutor Peter the Deacon describes the nature of the work, leading into Gregory's words with the lines: ' $\&$ forðon se eadega sanctus Gregorius ærest wæs sprecende be him selfum pisum wordum \& pus cwæð' (Hecht 1900, p. 2, 1. 22-p. 3, 1. 1) ('and therefore the blessed Saint Gregory was at first speaking these words by himself, and thus said'). Unlike the Pastoral Care, Gregory is clearly established as the speaker.

18 'King Alfred's mass priest John'. This note appears in Cambridge, Trinity College, R.5.22 (tenth or eleventh century) and Cambridge, Univ. Library, Ii.2.4 (later eleventh century); both comments are 'in the hand of the original scribe. It was presumably entered as a marginal note in the common source of the two manuscripts, which was the copy sent to Wulfsige of Sherborne, or derived from it' (Godden 2011, p. 465 , no. 66$)$.
} 
(2007, pp. 169-170), maintained through 'ambiguity of the translatory firstperson'. ${ }^{19}$ Though this ambiguity may not be an entirely deliberate literary device, the result is a striking merging of the two voices, pope and king, with the king's presence emerging dominant.

The ambiguity of the first person in the Pastoral Care stands in direct contrast to several other Alfredian translations, namely, the Boethius, the Soliloquies and the Orosius. $^{20}$ Godden (2004, pp. 5-6) has shown that the authors of these texts make particular effort to emphasise the presence of the authors of the original works, despite the fact that narrators are often made to speak words that do not occur in the original Latin text. Hurley (2013, p. 411) explores this narrative conceit in the Orosius, focussing on the recurring phrase 'cwæð Orosius', which in fact never precedes something which has been drawn from the Latin text. Needless to say, there is no corresponding 'cwæð Gregorius' in the Pastoral Care. These other translations insist that their author-figures are, respectively, Boethius, Augustine and Orosius. In the Pastoral Care the presence of the prefaces, and absence of any reference to Gregory in the main text, creates an authorial voice that is firmly located in the royal court of ninth-century Wessex.

\section{The Quotations}

Before proceeding to the biblical quotations themselves, it is worth drawing attention to the way they are presented in the Pastoral Care. In one of his most noticeable departures from Gregory's text, the Anglo-Saxon translator frequently specifies the name of the original speaker of the quotation (Schreiber 2015, p. 180). Thus the narrator often invokes Solomon, thought to be the author of several biblical books. $^{21}$ The significance of the Alfred-persona speaking Solomon's words should be emphasised, as Solomon was an important royal model for Alfred. ${ }^{22}$ Moreover, the frequency of the word Jurh ('through') in the introductions to the quotations is significant, as it suggests that the biblical speaker is channelling God's wisdom, a process that implicitly provides a model for the Alfred-persona's own channelling of this wisdom. For example, a quotation from Ecclesiasticus is prefaced with the phrase: 'Bi ðam wæs suiðe ryhte gecueden ðurh sumne wisne monn' (Sweet

\footnotetext{
${ }^{19}$ Pratt (2007, pp. 169-170) argues that the potential for 'royal presence' is also observable in the Prose Psalms, where the first person is likewise ambiguous.

20 These are, respectively, translations of Boethius's De consolatione Philosophiae, Augustine's Soliloquia and Orosius's Historiae adversus paganos.

21 These are 'part of the book of Proverbs', Ecclesiastes, the Song of Solomon, 'the book known as the Wisdom of Solomon', as well as 'two biblical psalms' (72 and 127) (Coogan 2016, p. 224).

22 See Vita Alfredi c. 76.
} 
$1871-872$, p. $119,11.21-22) .{ }^{23}$ It is important to note that though the words are said only through the man, he is nonetheless wis. $^{24}$

In the survey of key biblical quotations that follows, some quotations will be subtly altered from their Latin source, while others remain close to what appears in the Regula pastoralis. In the first example, from Matthew 20, there is little change from the Latin; however, the significance of hearing these biblical words in the king's voice should not be underestimated. Voicing Christ Himself, the Alfredpersona says: 'Ne com ic to ðon on eorðan ðæt me mon ðenode, ac to ðon ðæt ic wolde ðegnian' (Sweet 1871-1872, p. 301, 1l. 2-3). ${ }^{25}$ This verse conveys the same humility portrayed in the Vita Alfredi, in which the king is shown to perceive kingship as a duty to carry out rather than a right to be enjoyed; the same sense of royal duty is evident in the king's concern for his people's wisdom as expressed in the prose preface to the Pastoral Care ${ }^{26}$ However, this quotation is a good example of the complex interplay of authority that takes place in the royal translation of biblical material. Speaking these words allows the Alfred-persona to echo another leader's humility. The issue of the ruler's humility is central to Gregory's own ideology, and to the Pastoral Care, making it a fertile text for the cultivation of this aspect of royal ideology. ${ }^{27}$ However, it should be remembered that this other leader is Christ, the ultimate leader of mankind. ${ }^{28}$ The act of channelling words ascribed to

\footnotetext{
23 'About that it was very rightly said through a certain wise man'. Cf. Regula pastoralis 2.6: 'recte per quendam sapientem dicitur' (Judic et al. 1992, vol. I, p. 212, 11. 144-145) ('it is rightly said by a man of wisdom' [Davis 1950, p. 65]). All bold emphasis in quotations is added.

24 Stanton (2002, p. 91) observes that mediators of divine wisdom, including translators, preachers and exegetes 'had in some measure to be divinely inspired'.

25 'I did not come to earth so that men would serve me, but so that I would serve'. Cf. Regula pastoralis 3.17; Matt. 20.28: 'Sicut Filius hominis non venit ministrari sed ministrare' ('even as the Son of man is not come to be ministered unto but to minister'). All quotations from and references to the Bible are from Fischer et al. (2007), except for the Psalter, for which Gregory uses the Romanum version, rather than the Gallicanum: for references to the Psalter, therefore, see Weber (1953); all translations of the Vulgate are from Swift and Kinney (2010-2013).

26 The idea that a king should serve his people, rather than be served, is captured in the image Asser gives of Alfred steering the ship of his kingdom to safety: 'Sed tamen ille solus divino fultus adminiculo susceptum semel regni gubernaculum, veluti gubernator praecipuus, navem suam multis opibus refertam ad desideratum ac tutum patria suae portum, quamvis cunctis propemodum lassis suis nautis' (Vita Alfredi c. 91; Stevenson 1959, p. 77, 11. 28-33) ('Yet once he had taken over the helm of his kingdom, he alone, sustained by divine assistance, struggled like an excellent pilot to guide his ship laden with much wealth to the desired safe haven of his homeland, even though all his sailors were virtually exhausted' [Keynes and Lapidge 1983, p. 101]).

27 See, for example, the case of Moses, who resisted the authority of rule, but ultimately submitted to it for the sake of humility: 'Ægðer ge he wolde ge he nolde, \& ðeah for eaðmodnesse geðafode' (Sweet 1871-1872, p. 51, 1. 10) ('he both would and would not, and yet because of humility he consented'). Markus (1997, p. 20) notes, moreover, that for Gregory, the virtue of humility was a means of resolving the tension between the contemplative life and the active life of pastoral care: through humility, he was able to take up office under the terms of submitting himself to God's calling.

${ }^{28}$ Karkov (2004) identifies in Alfredian writings and material culture a tendency to present the ideal ruler, and therefore Alfred himself, as a type of Christ (see pp. 28-32 on the Pastoral Care and the Alfred Jewel, pp. 39-40 on the preface to the Domboc, and p. 48 on the Vita Alfredi).
} 
Christ, in the first person, bolsters the king's authority, under the guise of an expression of humility. ${ }^{29}$

Elsewhere, Gregory cites from the preceding verses of Matthew 20, and, in their Old English translation, we can likewise witness the implicit construction of royal authority:

Wite ge ðætte ðioda kyningas bioð ðæs folces waldendas, ond ða ðе ðone anwald begað hi beoð hlafordes gehatene; ne sie hit ðonne na sua betweoxn eow, ac sua hwelc swa wille betweoxn eow fyrmest beon, se sceal beon eower ðegn, ond sua hwelc sua wille betweoxn eow mæst beon, sie se eower ðeow [...] (Sweet 1871-1872, p. 121, 1l. 2-7). ${ }^{30}$

The primary departure from Gregory's text and from Scripture comes in the first clause. In the Vulgate, Christ says:

[25] [...] scitis quia principes gentium dominantur eorum et qui maiores sunt potestatem exercent in eos [26] non ita erit inter vos sed quicumque voluerit inter vos maior fieri sit vester minister [27] et qui voluerit inter vos primus esse erit vester servus (Matt. 20.25-27). ${ }^{31}$

The phrase principes gentium becomes 'ðioda kyningas', a translation choice appropriate for contemporary West-Saxon rule. ${ }^{32}$ The verb 'dominantur' becomes the more neutral noun-phrase 'folces waldendas': the Old English quotation appears to describe a familiar situation, without the implication of immoral subjugation that is present in the Latin. It is simply recorded that those who exercise power are named lords. The alterations to this opening clause change the whole meaning of the quotation, especially if we remember that the voice speaking these words belongs to an Anglo-Saxon king. The first clause of this quotation could perhaps be understood as the establishment of the norms of leadership — kings and lords have power over other people-while the latter half could be understood as a reminder that only kings and lords are entitled to such authority. Nobody else should reach for positions of power. It is worth considering the audience of the Pastoral Care: if the speaker of the quotation is Alfred, who is the 'ge'? The warning makes sense if we imagine an episcopal readership, as implied by the prose preface-bishops should not squabble for power-and likewise if we think of the lesser aristocracy reading the text, the

\footnotetext{
29 In the Regula pastoralis, as in Scripture, these are words said about Christ (Judic et al. 1992, vol. II, p. 362, 11. 17-18). The same quotation appears in Regula pastoralis 2.6, as part of a longer excerpt from Matthew, discussed below (Judic et al. 1992, vol. II, p. 214, 11. 153-154), and is translated in the third person in the Old English (Sweet 1871-1872, p. 121, 11. 7-9).

30 'You know that the kings of nations are the rulers of the people, and those who exercise power are called lords; it will not then be thus between you, but whoever between you would be first, he shall be your retainer, and whoever between you would be the greatest, he will be your servant'. Cf. Regula pastoralis 2.6.

31 ' $[25]$ [...] You know that the princes of the Gentiles lord it over them and they that are the greater exercise power upon them. [26] It shall not be so among you, but whosoever will be the greater among you, let him be your minister. [27] And he that will be first among you shall be your servant'.

32 Elsewhere, principes is translated with ealdormen: see the translation of Hos. 8.4 (Sweet 1871-1872, p. 27, 11. 14-15).
} 
quotation perhaps serves as a warning to ealdormen to not get above themselves. ${ }^{33}$ The authority of the biblical voice, here Christ's, lends power to such a warning. These quotations support the general ideology behind Alfred's kingship as presented in the prose preface to the translation, Asser's Vita Alfredi and other royal documents: humble, but nonetheless authoritative, ruling with right and with justice, which accords with the Gregorian ideal ruler as presented in the Regula pastoralis. The next quotations to be considered share not only ideological similarities with other royal documents, but also vocabulary. This creation of royal discourse is one of the most powerful assertions of the king's authority.

In another quotation from the New Testament, the Alfred-persona repeats the words of Timothy: 'Ne scyle nan Godes ðeow hine selfne to ungemetlice bindan on woruldscipum, ðylæs he mislicige ðæm ðe he ær hine selfne gesealde' (Sweet 1871-1872, p. 131, 11. 1-3). ${ }^{34}$ In Gregory's text, this quotation reads: 'Nemo militans Deo implicat se negotiis saecularibus, ut ei placeat cui se probauit' (Regula pastoralis 2.7; Judic et al. 1992, vol. I, p. 220, 11. 41-43). ${ }^{35}$ The Old English contrasts with the Latin quotation in its moderation of Timothy's words: in Alfred's voice, the injunction against any 'soldier to God', which is translated as 'servant of God', becoming involved with secular things is qualified with the phrase 'to ungemetlice' ('too immoderately'). ${ }^{36}$ Some allowance is made for the 'woruldscipum'. We may be reminded here of the prose preface to this translation, in which Alfred commands his bishops to remove themselves from worldly things 'swæ ðu oftost mæge' (Sweet 1871-1872, p. 5, 1. 3) ('as often as you can'), ${ }^{37}$ acknowledging, as the translation of the Timothy quotation does, that even holy men cannot, and perhaps should not, be wholly removed from worldly affairs. ${ }^{38}$ This pragmatic emendation is in line with several adaptations elsewhere in the Alfredian translations, most notably perhaps in the long addition to the Boethius, in which the speaker defends his right to the materials which allow him to govern well (Btext, c. 17; Godden and Irvine 2009, vol. I, pp. 277-278). ${ }^{39}$ Ungemetlice not only reflects an Alfredian ideological trend, but is also a piece of characteristic Alfredian

\footnotetext{
33 Godden (2011, pp. 459-461) argues that the prose preface disguises the fact that bishops are the true intended recipients of the translation through its story of 'national renewal', in which laymen are the beneficiaries of Alfred's educational programme.

34 'God's servant shall not too immoderately bind himself in worldly affairs, the less he displease the one to whom he previously gave himself'. Cf. 2 Tim. 2.4.

35 'No man, being a soldier to God, entangleth himself with secular business, that he may please him to whom he hath engaged himself' (Davis 1950, p. 69).

36 Pratt (2007, p. 207) identifies the introduction of to ungemetlice at this point as a 'characteristic qualification'.

37 Removal from the occupations and responsibilities of this world in favour of spiritual contemplation is likewise advocated in Gregory's preface to his Dialogi (Moricca 1924, pp. 13-15).

38 The verb geamettian ('to 'empty'/free oneself') appears both in the lines following the quotation from 2 Timothy and in the lines of the prose preface mentioned above (Sweet 1871-1872, p. 131, 1. 5 and p. 5 , 1. 3), perhaps indicating the influence of this part of the translation on the preface; see Pratt (2007, p. 207).

39 Bately (2015, p. 134) observes that the four "royal" translations (Pastoral Care, Boethius, Soliloquies and the Prose Psalms) often tone down condemnation of worldly goods and pleasures, by condemning not these things themselves but immoderate enjoyment of them: she refers to the quotation from 2 Timothy in the Pastoral Care as an example of such toning down.
} 
vocabulary. The combined occurrences of both adjective (ungemetlic) and adverb (ungemetlice) total 55 in the Pastoral Care. ${ }^{40}$ There are 26 occurrences each in both the Boethius and the Orosius, and 7 in the Soliloquies. Across all the works of Ælfric there are only 6 occurrences of both adjective and adverb. This is by far the most common group of texts in which these words appear. ${ }^{41}$ The introduction of this qualifying adverb therefore aligns the biblical quotation not only with the speaker's ideals, but also with the vocabulary of wider Alfredian discourse.

The adverb ungemetlice occurs elsewhere in the translation of scriptural quotations in the Pastoral Care. The Old English translation of Gregory's quotation of James 4.4 is near identical to the Latin, except for the phrase to ungemetlice: 'Swa swa Iacobus sæde se apostol, ða he cwæð: Swa hwa swa wille bion ðisse weorlde freond to ungemetlice, he bið gehaten Godes feond' (Sweet 1871-1872, p. 421, 11. 33-35). ${ }^{42}$ As with the quotation of 2 Timothy, the Alfredian version of the biblical verse becomes more lenient and more understanding of the necessity of engaging with worldly things. Similar qualification of scriptural strictures is evident in the translation of a quotation from Ecclesiastes, ascribed in the Old English text to Solomon: 'Ac gehiere ge feohgitseras hwæt be eow gecweden is on Salomonnes bocum, hit is gecweden: Ne wyrð se gitsere næfre full feos, and se ðe woruldwelan lufað ungesceadwislice, ne cymð him of ðæm nan wæsðm' (Sweet 1871-1872, p. 331, 11. 5-7). ${ }^{43}$ The differences from Gregory's text here are readily apparent: 'Cum augendis pecuniis inhiant, audient quod scriptum est: Auarus non impletur pecunia; et qui amat diuitias, fructus non capiet ex eis' (Regula pastoralis 3.20; Judic et al. 1992, vol. II, p. 390, 11. 127-129). ${ }^{44}$ The emphasis on voice, evident in the Regula pastoralis but amplified in the Old English, should first be noted. ${ }^{45}$ This frame for the quotation heightens the reader's awareness that these words were originally said by King Solomon: the reader who remembers the prose preface knows that they are now being spoken by King Alfred. The echo of Solomon's voice adds another layer of authority to the quotation that is spoken in Alfred's voice. ${ }^{46}$

The major departure in the quotation itself is the introduction of ungesceadwislice ('foolishly'). As I shall argue in greater detail in the following quotations, and as is easily grasped from a reading of the prose preface of the Pastoral Care,

\footnotetext{
40 All figures for frequencies of Old English words have been calculated using the Dictionary of Old English (DOE) Corpus (diPaolo Healey et al. 2009); henceforth DOE Corpus.

41 The highest number of occurrences in any other single text, Alexander's Letter to Aristotle, is only 5.

42 'Just as James the Apostle said, when he declared: Whoever will be too immoderately the friend of this world, he will be called the enemy of God'; cf. Regula pastoralis 3.30.

43 'But hear you avaricious ones what is said about you in Solomon's book, it is said: The avaricious man will never be full of money, and he who loves worldly wealth foolishly, no fruit will come to him of that'; cf. Eccles. 5.9.

44 'As they gape for an increase of their monies, let them hear what Scripture says: A covetous man shall not be satisfied with money, and he that loveth riches shall reap no fruit from them' (Davis 1950, p. 157).

45 Davis's translation of Gregory is misleading in its use of 'says', as the Latin has 'scriptum est', literally, 'what is written': the only reference to voice in the Latin frame to the quotation is 'audient'.

46 This emphasis on hearing the words of Scripture is significant, as Toswell (2014, p. 70) observes that, according to Asser, at least, 'Alfred's engagement with biblical texts was remarkably aural', rather than visual, in that he would have had Scripture read aloud to him (see Vita Alfredi cc. 81 and 88).
} 
Alfredian royal documents often emphasise the importance of wisdom, especially divine wisdom. The use of ungesceadwislice therefore aligns this Solomonic maxim with Alfredian ideology: it is acceptable to pursue wealth, as long as one does it prudently. ${ }^{47}$ Moreover, ungesceadwis, along with its derivatives, appears commonly in Alfredian texts, with 10 occurrences in the Pastoral Care and 11 in the Boethius. The root of this adjective, gesceadwis, has particular Alfredian associations, as in both the Boethius and the Soliloquies Gesceadwisnes ('Reason') is a personified speaker, in the former as variation on Wisdom (Boethius's Philosophia) and in the latter as Augustine's Ratio. ${ }^{48}$ Like ungemetlice, ungesceadwislice reflects both the Alfredian ideology of wisdom and moderation, and the specific choice of vocabulary in Alfredian texts.

The pursuit of wisdom is central to Alfredian ideology, whether it is the practical wisdom of using wealth carefully, as in the Pastoral Care, or the divine wisdom that leads one to the true good in the Boethius. Asser repeatedly emphasises Alfred's wisdom and his desire for learning. ${ }^{49}$ The great lament of the prose preface to the Pastoral Care is, of course, the decline of Latin learning and accompanying loss of wisdom in the kingdoms of the Anglo-Saxons. ${ }^{50}$ Many of the translated biblical quotations in the Pastoral Care contribute to the construction of this ideology through subtle alterations: their emphasis on the centrality of wisdom is a reminder of Alfred's devotion to wisdom as expressed elsewhere in royal documents. For example, the translator introduces the word wisdom into one psalm quotation where there is no call for it in his source text: ${ }^{51}$ 'Be ðæm cwæð se psalmscop: Min mod \& min wisdom me forlet' (Sweet 1871-1872, p. 273, 11. 13-14). ${ }^{52}$ The Regula pastoralis has cor ('heart') in the place of the word-pair mod and wisdom (Regula pastoralis 3.14; Judic et al. 1992, vol. II, p. 342, 1. 27). ${ }^{53}$ While $\bmod$ is an understandable translation of cor, it is significant that the translator chooses to

\footnotetext{
47 In fact, this philosophy is itself Solomonic in essence, as Solomon was rewarded for his pursuit of wisdom with material riches (I Kings 3.5-14).

48 Gesceadwis, along with all its derivatives, appears 52 times in the Pastoral Care, 80 times in the Boethius and 21 times in the Soliloquies: these figures include searches for the variant spellings gescadwis and gescaeadwis. It is noteworthy that the only poetry in which the word appears is the Metres of Boethius (4 occurrences).

49 Vita Alfredi cc. 22, 25, 42, 76-78, 88-89, 99.

50 Bately (1980, p. 7) reminds us that Alfred's goal, as expressed by the prose preface, is 'to restore not literacy, not culture, not education in general-though these are all steps on his way-but what he describes as wisdom, 'wisdom".

51 Quotation of the Psalms has recently been discussed by Lawton (2017a, pp. 61-66 and b) in the light of what he calls 'public interiorities', by which he means pieces of text or speech that have been revoiced, and in being re-voiced can be refashioned.

52 'The Psalmist said about that: My mind and my wisdom have abandoned me'; cf. Ps. 39.13. Heorte is the only gloss offered for cor here in Pulsiano's survey (2001, p. 579) of Anglo-Saxon glossed psalters. The Prose Psalms translation reads 'Min heort and min mod me forleton' (Ps. 39.14; O'Neill 2001, p. 148). Though this verse, 'cor meum dereliquit me', appears under 39.13 in the Romanum and Gallicanum Psalters, in the Vespasian Psalter, as in the Prose Psalms, it appears under 39.14 (Kuhn 1965, p. 37).

53 This is likewise the reading in the Romanum Psalter, as well as the Gallicanum.
} 
introduce wisdom. Though O'Neill (2001, p. 79) puts this addition down to the influence of the preceding quotation from Proverbs 5.1-2, which includes the word sapientia ('wisdom'), it is nonetheless a departure from the source. ${ }^{54}$ The effect of this alteration is to locate wisdom at the spiritual and devotional centre of the psalmist, in the place of the emotional faculty of the heart. Moreover, it is perhaps no coincidence that the word-pair selected here is mod and wisdom, the names of the two speakers in the dialogue of the Old English Boethius. The presence of Alfred's voice (introduced in the framing prefaces to both texts) reinforces the overlapping ideology of these two translations.

The word wisdom is likewise added to two further biblical quotations in this chapter. ${ }^{55}$ The next quotation, from 2 Samuel, comes a line after the psalm quotation mentioned above, and O'Neill suggests that the mention of wisdom is similarly inspired by the first biblical quotation in this section, from Proverbs 5.1-2 (O’Neill 2001, p. 79): 'Đin ðeow hæfð nu funden his wisdom, ðæt is ðæt he hine gebidde to ðe' '(Sweet 1871-1872, p. 273, 1l. 15-16). ${ }^{56}$ Gregory's text, following the Vulgate, has cor ('heart') in the place of Old English wisdom (Regula pastoralis 3.14; Judic et al. 1992, vol. II, p. 342, 1. 28). While the previous quotation made use of the word-pair mod and wisdom, here wisdom has completely replaced the emotional faculty of the heart, and becomes the sole faculty of the individual's devotion to the divine. Later in the chapter, focus on wisdom transforms the sense of a quotation from Proverbs, attributed in the Old English to Solomon: ${ }^{57}$ 'Ac se wisa Salomon sædde ðætte swiðe deop pol wære gewered on ðæs wisan monnes mode, and swiðe lytel unnyttes utfleowe' (Sweet 1871-1872, p. 279, 11. 14-16). ${ }^{58}$ The original proverb makes no reference to wisdom, and Gregory does not mention Solomon: 'in bona etiam parte iterum dicitur: Aqua profunda, uerba ex ore uiri' (Regula pastoralis 3.14; Judic et al. 1992, vol. II, p. 346, 11. 93-94) ${ }^{59}$ Evocation of the Old Testament king's voice heightens the awareness of the layers of voices present in the text. The reference to Solomon's wisdom contributes to the ideal of wise kingship, found also in Asser's Vita Alfredi, and serves as a reminder that,

\footnotetext{
54 This quotation reads 'Fili mi, attende sapientiam meam, et prudentiae meae inclina aurem tuam, ut custodias cogitationes' (Regula pastoralis 3.14; Judic et al. 1992, vol. II, p. 342, 11. 22-24) ('My son, attend to my wisdom, and incline thy ear to my prudence, that thou mayest guard thy thoughts' [Davis 1950, p. 130]). In the Old English this is translated: 'Sunu min, ongiet minne wisdom \& minne wærscipe, \& behald ðin eagean \& ðin earan to ðæm ðætte ðu mæge ðin geðoht gehealdan' (Sweet 1871-1872, p. 273, 11. 8-10) ('My son, perceive my wisdom and my prudence, and direct your eyes and your ears so that you may guard your thought').

55 This is Regula pastoralis chapter 3.14: 'Quod aliter ammonendi sunt nimis taciti atque aliter multiloquio uacantes' (Judic et al. 1992, vol. II, p. 340, 11. 1-2) ('How to admonish the taciturn and the talkative' [Davis 1950, p. 129]).

56 'Your servant has now found his wisdom, that is that he prays to you'; cf. 2 Sam. 7.27.

57 The quotation which precedes this one is attributed to Solomon, in both the Latin (Judic et al. 1992, vol. II, p. 346, 11. 90-91) and the Old English (Sweet 1871-1872, p. 279, 11. 11-13), and thus may have influenced the attribution here.

58 'But the wise Solomon said that a very deep pool was damned up in the wise man's mind, and very little flowed out uselessly'; cf. Prov. 18.4.

59 'it is again said in a good sense: Words from the mouth of a man are as deep water' (Davis 1950, p. 133).
} 
though the wise king Solomon originally said these words, they are now re-voiced by the current wise king of the West Saxons. ${ }^{60}$ The translation of the quotation itself attempts to make sense of the rather obscure biblical proverb, likening thoughts that are held in silence, rather than spilled uselessly in idle chatter, to the water of a deep pool. This, of course, is one example of the water imagery that inspired the metrical epilogue to the Pastoral Care, which relies upon a similar metaphorical system (Isaacs 1965, pp. 548-549; Whobrey 1991, pp. 179-185).

There is, however, an occasion on which a reference to wisdom in a biblical quotation is removed in the Old English translation. The Regula pastoralis reads: 'Vnde et bene quidam sapiens dicit: Sapientia abscondita et thesaurus inuisus, quae utilitas in utrisque?' (Regula pastoralis 3.25; Judic et al. 1992, vol. II, p. 428, 11. 17-18). ${ }^{61}$ In the Old English this becomes: 'Be ðæm cwæð Salomon: Hu nytt bið se forholena cræft oððe ðæt forhydde gold?' (Sweet 1871-1872, p. 377, 11. 6-7). ${ }^{62}$ Though the reference to wisdom has been removed, it has been replaced with the word craft, another word of great importance in the Alfredian context, with several different though interconnected meanings, including 'skill' and 'virtue' (Discenza 1997; Clemoes 1992). Moreover, wisdom and craft are closely connected in the Old English Boethius. As Mod says in his defence of good governance: 'ælc cræft and ælc anweald bið sona forealdod and forswugod, gif he bið buton wisdome; forðæm ne mæg non mon nænne cræft forðbringan buton wisdome' (B-text, c. 17, 1. 22-24; Godden and Irvine 2009, vol. I, pp. 277-278). ${ }^{63}$ The identification of craft with wisdom aligns the quotation more closely with the ideology expressed elsewhere in the Alfredian corpus.

As I have argued, wisdom is central to the Alfredian ideology. Another characteristic feature of some royal documents is the pairing of wealth and wisdom, perhaps most notably in the prose preface to the Pastoral Care (Sweet 1871-1872, p. 5, 11. 13-14 and 17), although also in one chapter of the Boethius. ${ }^{64}$ Just as the Pastoral Care-translator often introduces the theme of wisdom into the biblical quotations, so does he also, on at least one occasion, shift the focus of a quotation onto material wealth. Gregory quotes from Psalm 104 in support of his argument that God grants earthly rewards in order to inspire people with hope for spiritual rewards, in this way rationalising the joy in material success found in the Old Testament in New Testament terms: 'Dedit eis regiones gentium, et labores populorum possederunt, ut custodiat iustificationes eius et legem eius exquirant'

\footnotetext{
${ }^{60}$ Solomon is also referred to as 'done snottran' (Sweet 1871-1872, p. 389, 1. 16). cf. Regula pastoralis 3.26 which has only 'per Salomonem dicitur' (Judic et al. 1992, vol. II, p. 440, 1. 44) ('said [...] by Solomon' [Davis 1950, p. 183]).

61 'Wherefore, a wise man said well: Wisdom that is hid, and treasure that is not seen, what profit is there in them both?' (Davis 1950, p. 177); cf. Ecclus. 20.32.

62 'About that said Solomon: How is concealed skill/virtue or hidden gold useful?'.

63 'every skill and every power will be immediately withered and silenced if it is without wisdom; for no man may produce any skill without wisdom'. See also B-text c. 7, 11. 95-96; c. 27, 11. 47-48; c. 32, 11. 31-33 and c. 36, 11. 13-15 (Godden and Irvine 2009, vol. I, pp. 254, 298, 308 and 338-339).

64 This is B-text c. 7, in which Wisdom claims 'sop wela' ('true riches') as his servant (11. 77-78, Godden and Irvine 2009, I, p. 254). There are several studies which treat this Alfredian pairing (Shippey 1979; Nelson 1986; Discenza 2001b).
} 
(Regula pastoralis 3.26; Judic et al. 1992, vol. II, p. 442, 11. 66-68). ${ }^{65}$ The Old English translation situates these rewards in tribal, Germanic terms: 'He him sealde ricu oðerra kynrena, and manigra folca gestreones hie wieoldon, to ðon ðæt hi his ryhtwisnesse geheolden, and his æ sohton' (Sweet 1871-1872, p. 391, 11. 3-5). ${ }^{66}$ The choice of cynren, for 'gentium', with its connotations of kin and blood-ties, evokes Germanic, tribal warfare based around warring kin groups. ${ }^{67}$ Likewise, the transformation of labores into gestreon brings to mind the custom, fundamental to Germanic warrior culture, of reaping precious battle-gear and loot from one's enemies. ${ }^{68}$ This treasure is representative of the honour the warrior wins in battle. It plays a central role in Germanic gift-exchange, a process in which warriors bring their loot to their king, who stores this treasure in the national hoard, before distributing it at a later date to ensure or reward the loyalty of his followers (Baker 2013, pp. 59-62). If we recall the presence of the king's voice in this translation, these overtones of heroic warrior culture become yet more pronounced. The Alfredpersona as presented in the prose preface is a king who is conscious of his nation's wellbeing in both spiritual and material terms: he understands that a successful nation requires both wela ('wealth') and wisdom ('wisdom'). By subtly adapting this psalm quotation, the Pastoral Care-translator legitimises the appreciation of material wealth through the dual authority of Scripture and the royal voice. ${ }^{69}$

\footnotetext{
65 'He gave them the lands of the Gentiles, and they possessed the labours of the people, that they might observe His justifications and seek after His law' (Davis 1950, p. 184); cf. Ps. 104.44-45.

66 'He gave them the kingdoms of other nations, and they controlled the treasure of many peoples, in order that they might hold to His justice, and seek His law'. See Cherniss (1972, p. 97) on the importance of a tribe's collective wealth in Germanic culture. See also the opening lines of Beowulf (11. 1-11a), which praise how Scyld Scefing subjugated neighbouring tribes and forced them to pay tribute to his people; this fictional account appears to be corroborated by Saxo Grammaticus's account of Skiold (Gesta Danorum 3.2 [3]; Friis-Jensen and Fisher 2015, vol. II, pp. 24-25).

67 The first main definition for cynren offered by the $D O E$ is 'family line, clan, tribe' (Cameron et al. 2007). In Anglo-Saxon glossed psalters the more neutral peod is preferred here (Junius, Arundel, Cambridge, Eadwine, Tiberius, Vitellius, Regius, Stowe, Lambeth, Salisbury and Vespasian); this data has been gathered using the DOE Corpus. This is also the word chosen by the poet of the Metrical Psalms (Ps. 104.39; Krapp 1933, p. 82). In the Prose Psalms, however, a different appearance of gentes is translated with cynren (Ps. 46.8; O'Neill 2001, p. 158): this is significant given the Alfredian association of the Pastoral Care and Prose Psalms. On the importance of the kin-group in early Germanic culture, see Wallace-Hadrill (1971, p. 15) and Green (1998, p. 49).

68 Words chosen by psalter glossators for labores here include gewin ('battle', 'labour' or 'gain') (Junius, Cambridge, Eadwine and Vespasian), chosen also by the Metrical Psalms poet, and geswinc ('labour') (Arundel, Tiberius, Vitellius, Regius, Stowe, Lambeth and Salisbury). Gestreon also translates as 'gain' or 'product', and so has some overlap with gewin, but it is significant that the Pastoral Care-translator selects gestreon over these other two words. For the definitions of gewin, geswinc and gestreon see Bosworth-Toller (1898-1921).

69 This attitude recalls the Pastoral Care-translation of Ecclesiastes 5.9, which makes allowance for the appreciation of worldly wealth, as long as it is not ungesceadwislic ('foolish').
} 


\section{Conclusions}

This article has drawn attention to the overlooked biblical quotations in the Old English Pastoral Care, ${ }^{70}$ and has shown that the subtle alterations the translator makes can be seen to support Alfredian ideology. While it may be that such additions occur throughout the Pastoral Care-translation, they are particularly effective in the biblical quotations, as these statements are bolstered by the dual authority of Scripture and the king. Here, the force of the quotation is impressed upon the reader by the mingled biblical and royal voices, along with the voice of Gregory himself: the effect of this multiplication of authorial voice is even greater in the quotations attributed to King Solomon, as here the royal voice is twofold. These biblical quotations represent an innovative use of vernacular translation. Whereas psalter glosses and the near word-for-word Mercian translations of Gregory's Dialogues and Bede's Historia ecclesiastica remain as close to their Latin sources as possible, the Pastoral Care is a transformation of its source. ${ }^{71}$ Scholars of the Alfredian corpus usually contrast the originality, ambition and freedom of the Boethius and Soliloquies with the relatively conservative approach of the Pastoral Care. ${ }^{72}$ However, the Pastoral Care represents a fundamental first step in the use of the vernacular for literary translation, as the freedom with which it treats Gregory's Regula pastoralis, and the biblical quotations embedded within it, results in an entirely new text, which is not only emphatically Anglo-Saxon, but demonstrably Alfredian.

Open Access This article is distributed under the terms of the Creative Commons Attribution 4.0 International License (http://creativecommons.org/licenses/by/4.0/), which permits unrestricted use, distribution, and reproduction in any medium, provided you give appropriate credit to the original author(s) and the source, provide a link to the Creative Commons license, and indicate if changes were made.

\section{References}

Baker, P. (2013). Honour, Exchange and Violence in Beowulf. Anglo-Saxon Studies 20. Cambridge: D. S. Brewer.

Bately, J. (1980). The Literary Prose of King Alfred's Reign: Translation or Transformation? An Inaugural Lecture in the Chair of English Language and Medieval Literature Delivered at

\footnotetext{
70 On biblical quotations added by the Old English translator in the Boethius, see Godden and Irvine (2009, vol. I, p. 67): Godden and Irvine note that the Boethius-author does not identify the several biblical quotations that he introduces. In his edition of the Old English Soliloquies, Carnicelli (1969, p. 29) provides commentary on 'the occasional scriptural passages added' by the translator; see the commentary on individual biblical quotations or references on pp. 101, 102, 104 and 106.

71 Bately (1988, p. 118) describes the Dialogues and the Old English Bede as 'occasionally so faithful to their originals that the result is unidiomatic'. For more on the prose style of the Dialogues, see Bately, pp. 120-123, and on the Old English Bede, pp. 123-125. However, there is also evidence that the translator of the Old English Bede adapted his source; George Molyneaux (2009, p. 1291) shows that the translator removes certain material from Bede's text, reducing references to the dating of Easter, and making no mention of either Pelagianism or the Synod of Whitby.

72 For example, Godden (2007, p. 13) argues that in 'translation method and intellectual ambition there is a huge gulf between the Pastoral Care on the one hand and the Consolation and Soliloquies on the other'.
} 
University of London King's College on 4th March 1980. London: King's College, University of London.

Bately, J. (1988). Old English Prose Before and During the Reign of King Alfred. Anglo-Saxon England, 17, 93-138.

Bately, J. (2015). Alfred as Author and Translator. In N. G. Discenza \& P. E. Szarmach (Eds.), $A$ companion to Alfred the Great. Brill's Companions to the Christian Tradition 58 (pp. 113-142). Leiden: Brill.

Bosworth, J. \& Toller, T. N. (Eds.). (1898-1921). An Anglo-Saxon Dictionary Online. "Gestreon", "Geswinc" and "Gewin". Comp. S. Christ and O. Tichý. Faculty of Arts, Charles University in Prague, 21 Mar 2010. http://bosworth.ff.cuni.cz/016193; http://bosworth.ff.cuni.cz/016284; http:// bosworth.ff.cuni.cz/016827. Accessed August 15, 2017.

Butler, E. (2010). Alfred and the Children of Israel. Notes \& Queries, 57, 10-17.

Cameron, A., Amos, A. C., diPaolo Healey, A. et al. (Eds.). (2007). Dictionary of Old English: A$H$ Online. Toronto: Dictionary of Old English Project, http://tapor.library.utoronto.ca/doe/. Accessed August 15, 2017. (DOE).

Carnicelli, T. A. (Ed.). (1969). King Alfred's Version of St. Augustine's Soliloquies. Cambridge, MA: Harvard University Press.

Cherniss, M. D. (1972). Ingeld and Christ: Heroic Concepts and Values in Old English Christian Poetry. Studies in English Literature 74. The Hague: Mouton.

Clemoes, P. (1992). King Alfred's Debt to Vernacular Poetry: The Evidence of ellen and craft. In M. Korhammer, K. Reichl, \& H. Sauer (Eds.), Words, Texts and Manuscripts: Studies in Anglo-Saxon Culture Presented to Helmut Gneuss on the Occasion of his Sixty-Fifth Birthday (pp. 213-238). Cambridge: D. S. Brewer.

Coogan, M. D., \& Chapman, C. R. (2016). A Brief Introduction to the Old Testament: The Hebrew Bible in Its Context (3rd ed.). New York: Oxford University Press.

Davis, H. (Trans.). (1950). Pastoral Care. Ancient Christian Writers 11. Westminster, MD; London: Newman Press; Longmans, Green \& Co.

diPaolo Healey, A., Wilkin, J. P., \& Xiang, X. (2009). Dictionary of Old English Web Corpus. Toronto: Dictionary of Old English Project.

Discenza, N. G. (1997). Power, Skill and Virtue in the Old English Boethius. Anglo-Saxon England, 26, 81-108.

Discenza, N. G. (2001a). Alfred's Verse Preface to the Pastoral Care and the Chain of Authority. Neophilologus, 85, 625-633.

Discenza, N. G. (2001b). Wealth and Wisdom: Symbolic Capital and The Ruler in the Translational Program of Alfred the Great. Exemplaria, 13, 433-467.

Discenza, N. G., \& Szarmach, P. E. (Eds.). (2015). A Companion to Alfred the Great. Brill's Companions to the Christian Tradition 58. Leiden: Brill.

Earl, J. W. (1989). King Alfred's Talking Poems. Pacific Coast Philology, 24, 49-61.

Fischer, B., et al. (Eds.). (2007). Biblia Sacra Iuxta Vulgatem Versionem (5th ed.). Stuttgart: Deutsche Bibelgesellschaft.

Friis-Jensen, K. (Ed.) \& Fisher, P. (Trans.). (2015). Gesta Danorum (2 Vols.). Oxford: Clarendon Press.

Godden, M. (1991). Biblical Literature: The Old Testament. In M. Godden \& M. Lapidge (Eds.), The Cambridge Companion to Old English Literature (pp. 206-226). Cambridge: Cambridge University Press.

Godden, M. (2004). The Translations of Alfred and His Circle, and the Misappropriation of the Past. H.M. Chadwick Memorial Lectures 14. Cambridge: Department of Anglo-Saxon, Norse and Celtic, University of Cambridge.

Godden, M. (2007). Did Alfred Write Anything? Medium Avum, 76, 1-23.

Godden, M. (2011). Prologues and Epilogues in the Old English Pastoral Care, and their Carolingian Models. JEGP, 110, 441-473.

Godden, M. \& Irvine S. (Eds. \& Trans.), Griffith M., \& Jayatilaka, R. (2009). The Old English Boethius: An Edition of the Old English Versions of Boethius's De Consolatione Philosophiae (2 Vols.). Oxford: Oxford University Press.

Green, D. H. (1998). Language and History in the Early Germanic World. Cambridge: Cambridge University Press.

Hecht, H. (Ed.). (1900). Bischofs Warferth von Worcester Übersetzung der Dialoge Gregors des Grossen über das Leben und die Wunderthaten italienischer Väter und über die Unsterblichkeit der Seelen. Bibliothek der Angelsächsischen Prosa 5. Leipzig: G. H. Wigand. 
Hurley, M. K. (2013). Time and Translation in the Old English Orosius. Journal of English and Germanic Philology, 112, 405-432.

Isaacs, N. D. (1965). Still Waters Run undiop. Philological Quarterly, 44, 545-549.

Judic, B. \& Rommel, F. (Eds.) \& Morel, C. (Trans.). (1992). Règle pastorale, 2 Vols, Sources Chrétiennes 381-382. Paris: Les Éditions du Cerf.

Karkov, C. (2004). The Ruler Portraits of Anglo-Saxon England. Anglo-Saxon Studies 3. Woodbridge: Boydell.

Ker, N. R. (1990). Catalogue of Manuscripts Containing Anglo-Saxon. Oxford: Clarendon Press.

Keynes, S. \& Lapidge, M. (Eds. \& Trans.). (1983). Alfred the Great: Asser's Life of King Alfred and Other Contemporary Sources. London: Penguin Books.

Krapp, G. P. (Ed.). (1933). The Paris Psalter and the Meters of Boethius ASPR 5. London: Routledge.

Kuhn, S. M. (Ed.). (1965). The Vespasian Psalter. Ann Arbor: University of Michigan Press.

Lawton, D. (2017a). Voice in Later Medieval English Literature: Public Interiorities. Oxford: Oxford University Press.

Lawton, D. (2017b). Psalms As Public Interiorities: Eleanor Hull's Voices. In T. Atkin \& F. Leneghan (Eds.), The Psalms and Medieval English Literature: From the Conversion to the Reformation (pp. 298-317). Cambridge: D. S. Brewer.

Markus, R. A. (1997). Gregory the Great and His World. Cambridge: Cambridge University Press.

Molyneaux, G. (2009). The Old English Bede: English Ideology or Christian Instruction? The English Historical Review, 124, 1289-1323.

Moricca, U. (Ed.). (1924). Gregorii Magni Dialogi. Fonti per la storia d'Italia pubblicate dall'Istituto storico italiano 57. Rome: Tip. del Senato.

Nelson, J. L. (1986). Wealth and Wisdom: The Politics of Alfred the Great. In J. Rosenthal (Ed.), Kings and Kingship. Acta 11 (pp. 31-52). Binghampton, NY: Center for Medieval and Early Renaissance Studies, State University of New York at Binghampton.

O'Neill, P. P. (Ed.). (2001). King Alfred's Old English Prose Translation of the First Fifty Psalms 104. Medieval Academy Books Cambridge, MA: Medieval Academy of America.

Orton, D. (2015). Royal Piety and Davidic Imitation: Cultivating Political Capital in the Alfredian Psalms. Neophilologus, 99, 477-492.

Pratt, D. (2007). The Political Thought of Alfred the Great. Cambridge: Cambridge University Press.

Pulsiano, P. (2001). Old English Glossed Psalters: Psalms 1-50. Toronto; London: University of Toronto Press.

Schreiber, C. (2003). King Alfred's Old English Translation of Pope Gregory the Great's Regula pastoralis and Its Cultural Context: A Study and Partial Edition According to All Surviving Manuscripts Based on Cambridge, Corpus Christi College 12. Münchner Universitätsschriften: Texte und Untersuchungen zur englischen Philologie 25. Frankfurt am Main: Lang.

Schreiber, C. (2015). Searoðonca hord: Alfred's Translation of Gregory the Great's Regula pastoralis. In N. G. Discenza \& P. E. Szarmach (Eds.), A Companion to Alfred the Great. Brill's Companions to the Christian Tradition 58 (pp. 171-199). Leiden: Brill.

Shippey, T. A. (1979). Wealth and Wisdom in King Alfred's Preface to the Old English Pastoral Care. The English Historical Review, 94, 346-355.

Stanton, R. (2002). The Culture of Translation in Anglo-Saxon England. Woodbridge: D. S. Brewer.

Stevenson, W. H. (Ed.). (1959). Life of King Alfred: Together with the Annals of St Neots Erroneously Ascribed to Asser. Oxford: Clarendon Press.

Sweet, H. (Ed. \& Trans.). (1871-1872). King Alfred's West-Saxon Version of Gregory's Pastoral Care, Parts 1 and 2. EETS 45 and 50, o.s. London: Oxford University Press.

Swift, E., \& Kinney, A. M. (Eds. \& Trans.). (2010-2013). The Vulgate Bible: Douay-Rheims Translation (6 Vols). Dumbarton Oaks Medieval Library 1, 4-5, 8, 13, 17, 21. Cambridge, MA: Harvard University Press.

Toswell, M. J. (2014). The Anglo-Saxon Psalter. Turnhout: Brepols.

Treschow, M. (2014). Godes Word for Vox Domini in Psalm 28 of the Paris Psalter: Biblical Translation and Alfredian Politics. Florilegium, 31, 165-180.

Wallace-Hadrill, J. M. (1971). Early Germanic Kingship in England and on the Continent. Oxford: Clarendon Press.

Weber, R. (Ed.). (1953). Le Psautier Romain et les autres anciens psautiers latins. Rome: Abbaye SaintJérôme.

Whobrey, W. T. (1991). King Alfred's Metrical Epilogue to the Pastoral Care. Journal of English and Germanic Philology, 90, 175-186. 